\title{
Mycobacterium tuberculosis RpfE-Induced Prostaglandin E2 in Dendritic Cells Induces Th1/Th17 Cell Differentiation
}

\author{
Hye-Soo Park, Seunga Choi, Yong-Woo Back, Kang-In Lee, Han-Gyu Choi * and Hwa-Jung Kim *D
}

Citation: Park, H.-S.; Choi, S.; Back, Y.-W.; Lee, K.-I.; Choi, H.-G.; Kim, H.-J. Mycobacterium tuberculosis RpfE-Induced Prostaglandin E2 in Dendritic Cells Induces Th1/Th17 Cell Differentiation. Int. J. Mol. Sci. 2021, 22, 7535. https://doi.org/ $10.3390 /$ ijms 22147535

Academic Editor: Toshio Hattori

Received: 31 May 2021

Accepted: 11 July 2021

Published: 14 July 2021

Publisher's Note: MDPI stays neutral with regard to jurisdictional claims in published maps and institutional affiliations.

Copyright: (c) 2021 by the authors. Licensee MDPI, Basel, Switzerland. This article is an open access article distributed under the terms and conditions of the Creative Commons Attribution (CC BY) license (https:// creativecommons.org/licenses/by/ $4.0 /)$.
Department of Microbiology and Department of Medical Science, College of Medicine, Chungnam National University, Daejeon 35015, Korea; 01027192188@hanmail.net (H.-S.P.); seungachoi@cnu.ac.kr (S.C.); lenpk@nate.com (Y.-W.B.); popigletoh@nate.com (K.-I.L.)

* Correspondence: ekdrms20000@cnu.ac.kr (H.-G.C.); hjukim@cnu.ac.kr (H.-J.K.)

Abstract: Prostaglandin E2 (PGE2) is an important biological mediator involved in the defense against Mycobacterium tuberculosis (Mtb) infection. Currently, there are no reports on the mycobacterial components that regulate PGE2 production. Previously, we have reported that RpfE-treated dendritic cells (DCs) effectively expanded the Th1 and Th17 cell responses simultaneously; however, the mechanism underlying Th1 and Th17 cell differentiation is unclear. Here, we show that PGE2 produced by RpfE-activated DCs via the MAPK and cyclooxygenase 2 signaling pathways induces Th1 and Th17 cell responses mainly via the EP4 receptor. Furthermore, mice administered intranasally with PGE2 displayed RpfE-induced antigen-specific Th1 and Th17 responses with a significant reduction in bacterial load in the lungs. Furthermore, the addition of optimal PGE2 amount to IL-2-IL-6-IL-23p19-IL-1 $\beta$ was essential for promoting differentiation into Th1/Th17 cells with strong bactericidal activity. These results suggest that RpfE-matured DCs produce PGE2 that induces Th1 and Th17 cell differentiation with potent anti-mycobacterial activity.

Keywords: tuberculosis; dendritic cell maturation; PGE2; Th1/Th17 differentiation; naïve T cell differentiation; multifunctional $\mathrm{T}$ cell

\section{Introduction}

Tuberculosis (TB), caused by Mycobacterium tuberculosis (Mtb), remains one of the most important infectious diseases worldwide. Mtb infections result in approximately two million deaths annually, indicating an urgent need for improved treatment and prevention strategies [1]. The only vaccine currently available, the Mycobacterium bovis BCG (Bacille Calmette-Guérin) vaccine, is both safe and cost-effective and efficiently protects children against early manifestations of TB [2,3]. However, BCG antigens do not persist for a sufficient amount of time to generate long-term effector memory $\mathrm{T}$ cells, limiting the efficacy of BCG against adult pulmonary TB [3-5]. The reciprocal induction of Th1 and Th17 cell responses plays an important role in establishing protective immune responses against TB [6]. Protection from Mtb is dependent on a robust Th1 response through IFN$\gamma$ secretion by antigen-specific $\mathrm{CD}^{+} \mathrm{T}$ cells; however, recent studies have emphasized the importance of the Th17 response in protective immunity against Mtb infection [7-9]. Hence, understanding the balance between Th1 and Th17 responses during infection and identifying novel proteins that simultaneously induce both Th1 and Th17 responses are crucial in the development of efficacious vaccines.

Eicosanoids, the biologically active lipid mediators derived from arachidonic acid, include prostaglandins, lipoxins, and leukotrienes. In particular, prostaglandin E2 (PGE2) plays an important role in regulating inflammatory responses. PGE2 is a key mediator of pyrexia, hyperalgesia, and arterial dilation, which increases blood flow to inflamed tissues and, in combination with enhanced microvascular permeability, results in edema. The relevance of this pathway in promoting inflammation is supported by the clinical use of cyclooxygenase inhibitors, which are effective anti-inflammatory agents that interfere with 
prostaglandin synthesis [10]. However, PGE2 can also exert anti-inflammatory properties and negatively regulate the functions of neutrophils, monocytes, and lymphocytes, particularly Th1 cells that produce IFN- $\gamma$ [11]. This paradox has puzzled many investigators for decades. PGE2 has been shown to exacerbate inflammation and disease severity in murine models of inflammatory bowel disease (IBD) and collagen-induced arthritis through the IL-23-IL-17 pathway [12,13]. These effects have been attributed to the action of PGE2 on innate cells, as PGE2 enhances the production of IL-23 and IL- $1 \beta$ in macrophages and dendritic cells (DCs), while down-regulating IL-12 production [14]. A recent report has shown that PGE2, together with IL-23, favors the expansion of human Th17 cells from peripheral blood mononuclear cells (PBMCs) and that PGE2 enhances IL-17 production induced by IL-23 from memory CD4 ${ }^{+} \mathrm{T}$ cells [15]. Th17 cells are a unique subset of effector $\mathrm{T}$ cells that are distinct from the Th1 and Th2 subsets [16-19], and they have been implicated as potent effectors of autoimmune disorders, such as multiple sclerosis, psoriasis, arthritis, and IBD [20-23]. IL-23 and IL-1 $\beta$ are crucial factors in the development of human Th17 cells $[22,24,25]$. Additionally, the TGF- $\beta$ - and IL-6-dependent Th17 cell population plays essential roles in chronic inflammation and autoimmunity [26].

Eicosanoids are functionally linked to the immune response that determines the control of Mtb infection in the host. Because the different outcomes of Mtb infection between 5-lipoxygenase (LO)- and cyclooxygenase-2-deficient mice have been reported [27]. Mtb stimulates antigen-presenting cells (APCs) to produce PGE2, which modulates the host immune response through EP2 and EP4 receptors. Mtb infection upregulates EP2 expression in $\mathrm{CD}^{+} \mathrm{T}$ cells, and $\mathrm{EP}^{-/-}$mice have shown higher susceptibility to $\mathrm{Mtb}$ infection [28]. IL-1 triggers PGE2 synthesis, type 1 IFNs counter-regulate the prostaglandin axis in Mtb-infected cells, and their networks determine the outcome of TB [29]. However, there are few reports on the effects of PGE2 on T-cell differentiation during Mtb infection and mycobacterial components that induce PGE2 production.

Mtb possesses five rpf homologues, rpfA-E, all of which were expressed in vitro and in vivo [30,31]. Among the genes encoding Rpf family members, $r p f E$ was expressed at a higher level during the exponential growth phase under normal culture conditions. Acidic stress and hypoxia also induced the higher relative expression of $r p f E$, indicating that $r p f E$ plays a role in cell survival during hypoxia-induced persistence and in the adaptation of Mtb to acid-induced stress conditions [32,33]. During the early stage of Mtb infection of mouse lungs, $\mathrm{Mtb}$ are actively growing in mouse organs, thus RpfE expression may be induced at a high level during this stage, making it an important antigen in inducing $\mathrm{T}$ cell responses. Despite the importance of Rpf family members in the pathogenesis of TB and in the development of vaccine to prevent Mtb infections, RpfE is less characterized than the other Rpf proteins [34]. We have previously reported that Mtb RpfE-matured DCs simultaneously induce both Th1 and Th17 cell polarization [6]. In this study, we further found that PGE2 produced by RpfE-activated DCs via the MAPK/NF- $\mathrm{KB} / \mathrm{COX} 2$ signaling pathway induces Th1 and Th17 responses mainly via the EP4 receptor. An optimal dose of PGE2 is essential for promoting differentiation into Th1/Th17 cells with strong bactericidal activity. Our data suggest that RpfE-matured DCs produce PGE2 that leads to Th1 and Th17 cell differentiation with the best anti-mycobacterial activity.

\section{Results}

\subsection{RpfE Induces PGE2 Production via MAPK/NF-kB Pathway in DCs}

Previously, we have reported that RpfE-matured DCs induce both Th1- and Th17polarized $\mathrm{T}$ cell responses [6]. PGE2 has been reported to facilitate the expansion of Th17 $[15,35,36]$ and Th1 [36,37]. To explore whether PGE2 could play a role in RpfEmediated Th1/Th17 differentiation, we first determined PGE2 production in RpfE-treated DCs. As shown in Figure 1A, RpfE stimulated DCs to secrete PGE2 in a dose-dependent manner. PGE2 production was significantly higher in DCs stimulated with $10 \mu \mathrm{g} / \mathrm{mL}$ RpfE than in those stimulated with $100 \mathrm{ng} / \mathrm{mL}$ LPS or untreated cells. Diverse stimuli regulate COX2 induction in immune cells, which mediates PGE2 production from 
arachidonic acid. DCs stimulated with $10 \mu \mathrm{g} / \mathrm{mL}$ RpfE showed significantly higher COX2 expression compared with untreated cells or LPS-treated cells (Figure 1B). Furthermore, RpfE-mediated PGE2 production was abrogated by pretreatment with an NS398 (COX2 inhibitor) (Figure 1C). Next, we determined that MAPK/NF- $\mathrm{kB}$ signaling was involved in RpfE-mediated PGE2 production in DCs. As expected, the RpfE-induced production of IL-1 $\beta$, IL-12p70 (for Th1 response), and IL-23p19 (for Th17 response) was significantly suppressed in DCs pretreated with pharmacological inhibitors of p38 (SB203580), ERK1/2 (U0126), and NF-KB (Bay 11-7082) but not of JNK (SP600125) (Figure 1D). These inhibitors, except the SP600125 and NS398, inhibited the production of PGE2. However, the NS398 pretreatment did not inhibit the production of RpfE-mediated Th1/Th17-related cytokines. Immunoblot analysis also showed that COX2 expression and NF- $\mathrm{KB}$ activation induced by RpfE were inhibited by SB203580, U0126, and Bay 11-7082, but NF-kB expression was not inhibited by NS398 (Figure 1E). These results suggest that MAPK and NF- $\mathrm{kB}$ signaling pathways are essential for the production of Th1/Th17-related cytokines and PGE2 as well as for COX2 expression in RpfE-stimulated DCs.

\subsection{PGE2 Produced by RpfE-Matured DCs Induces Th1 and Th17 Differentiation Mainly via EP4 Receptor}

Next, we investigated whether cytokines and PGE2 produced by RpfE-stimulated DCs could affect Th1 and Th17 differentiation. DCs pretreated with a pharmacological inhibitor were matured with RpfE and then co-cultured with splenocytes from Mtb-infected mice. The NS398 and all pharmacological inhibitors except the SP600125 significantly suppressed the production of IFN- $\gamma$ and IL-17A cytokines (Figure 2A) and the expression of T-betinducing Th1 response and RoR $\gamma$ t-inducing Th17 response (Figure 2B). PGE2 induces Th1 and/or Th17 differentiation through EP2 and EP4 receptors $[35,36]$. Therefore, we determined whether EP receptors are involved in RpfE-induced Th1 and Th2 responses. Under the same conditions as shown in Figure 2A, the production of RpfE-mediated IFN$\gamma$ and IL-17A was significantly suppressed by pretreatment with EP2 or EP4 antibody before co-culturing with splenocytes. The expression of IFN- $\gamma$ and IL-17A was significantly inhibited by EP4 antibody than EP2 antibody compared to untreated conditions (Figure 2C). Simultaneous treatment with the two antibodies significantly inhibited cytokine production compared to the single antibody treatment. RpfE-mediated T-bet expression was also significantly inhibited by EP4 antibody and slightly inhibited by EP2 antibody, but their inhibition was enhanced by co-treatment with both antibodies (Figure 2D). Expression of RoR $\gamma \mathrm{t}$ was prominently inhibited by the EP4 antibody but not by the EP2 antibody. Next, to confirm that these differentiated T cells play a role in controlling Mtb infection, the antibacterial activity of the T cells activated by RpfE-treated DCs was determined under conditions with or without pretreatment with EP2/4 antibodies. When T cells purified from splenocytes activated with RpfE-matured DCs were co-cultured with Mtb-infected macrophages, the growth of intracellular Mtb was significantly inhibited compared to that in non-activated T cells (Figure 2E). The T cells treated with EP4 antibody before coculturing with Mtb-infected macrophages did not show significant inhibition of Mtb growth Although EP2 antibody-treated T cells still showed significant Mtb growth inhibition, their anti-bactericidal activity was lower than that of untreated T cells. The inhibition of RpfEmediated Mtb growth was completely abolished by neutralization of EP4 and EP2 with both the antibodies. Taken together, these results suggest that PGE2 produced by RpfEstimulated DCs induces Th1 and Th17 responses mainly via the EP4 receptor and partly via the EP2 receptor, which inhibits intracellular Mtb growth. 
A
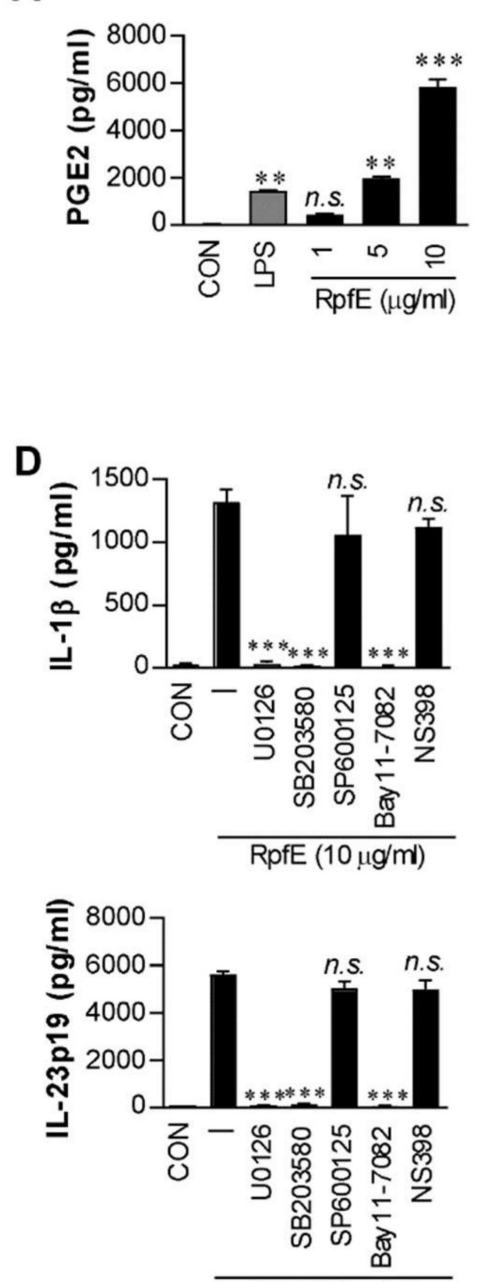

$\operatorname{RpfE}(10 \mu g / m)$
B
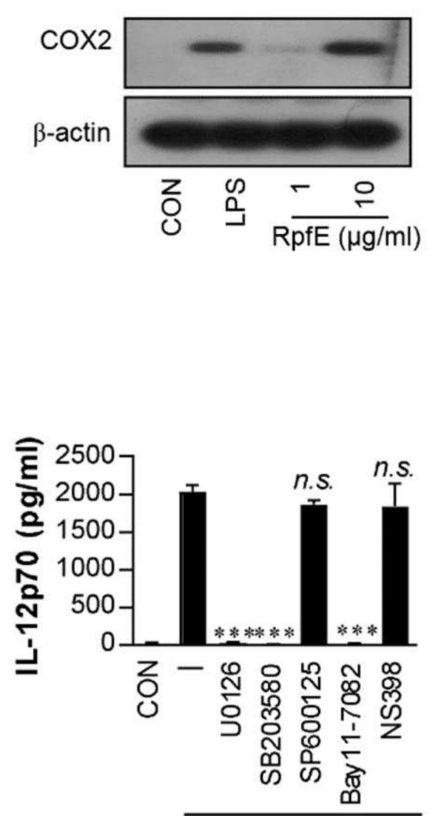

$\operatorname{RpfE}(10 \mu \mathrm{g} / \mathrm{m})$

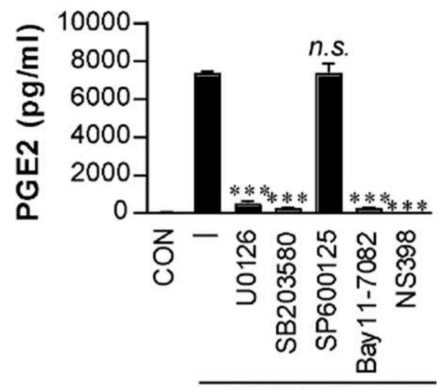

$\operatorname{RpfE}(10 \mu \mathrm{g} / \mathrm{m})$
C

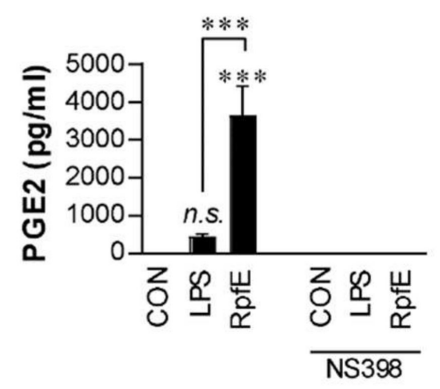

E

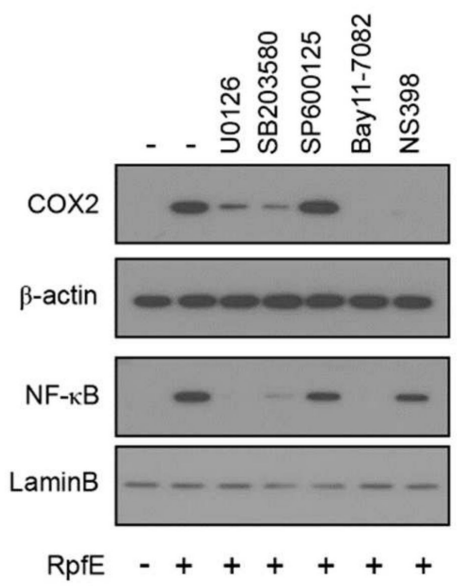

Figure 1. Mycobacterium tuberculosis (Mtb) RpfE produces prostaglandin E2 (PGE2) in activated dendritic cells (DCs) via the MAPK/NF-kB/COX2 signaling pathway. (A) DCs $\left(1 \times 10^{6}\right.$ cells $\left./ \mathrm{mL}\right)$ were cultured in the presence of 1,5 , or $10 \mu \mathrm{g} / \mathrm{mL}$ RpfE or $100 \mathrm{ng} / \mathrm{mL}$ LPS for $24 \mathrm{~h}$, and the levels of PGE2 in the culture supernatant were quantified using ELISA. Data are the mean $\pm \mathrm{SD}$ from three independent experiments; ${ }^{* *} p<0.01$ and ${ }^{* * *} p<0.001$ compared to untreated DCs. n.s.: no significant difference. (B) DCs were treated with 1 or $10 \mu \mathrm{g} / \mathrm{mL}$ RpfE or $100 \mathrm{ng} / \mathrm{mL}$ LPS for $4 \mathrm{~h}$. Cell lysates were subjected to SDS-PAGE, and immunoblotting analysis was performed using COX2 antibody. $\beta$-actin was used as the loading control for the cytosolic fraction. (C) DCs were treated with pharmacological inhibitors of NS398 (COX2 inhibitor, $10 \mu \mathrm{M}$ ) for $1 \mathrm{~h}$ prior to treatment with $10 \mu \mathrm{g} / \mathrm{mL}$ RpfE or $100 \mathrm{ng} / \mathrm{mL}$ LPS for $24 \mathrm{~h}$. The levels of PGE2 in the culture media were determined using ELISA. Data are the mean \pm SD from three independent experiments; ${ }^{* * *} p<0.001$ compared to untreated DCs. n.s.: no significant difference. (D) DCs were treated with pharmacological inhibitors of p38 (SB203580, $20 \mu \mathrm{M}), \mathrm{ERK} 1 / 2$ (U0126, $10 \mu \mathrm{M})$, JNK (SP600125, $20 \mu \mathrm{M})$, NF- KB (Bay11-7082, $20 \mu \mathrm{M})$, and NS398 (10 $\mu \mathrm{M})$ for $1 \mathrm{~h}$ prior to treatment with $10 \mu \mathrm{g} / \mathrm{mL}$ RpfE for $24 \mathrm{~h}$. The levels of IL-1 $\beta$, IL-12p70, IL-23p19, and PGE2 in the culture media were determined using ELISA. Data are the mean $\pm \mathrm{SD}$ from three independent experiments; ${ }^{* * *} p<0.001$ compared to RpfE treated DCs. n.s.: no significant difference. (E) DCs were treated with pharmacological inhibitors for $1 \mathrm{~h}$ prior to treatment with $10 \mu \mathrm{g} / \mathrm{mL} \mathrm{RpfE} \mathrm{for} 4 \mathrm{~h}$. Cell lysates were subjected to SDS-PAGE, and immunoblotting analysis was performed using COX2 or NF- $\mathrm{kB}$ antibodies. $\beta$-actin and Lamin B were used as the loading controls for the cytosolic and nuclear fractions, respectively. 
A

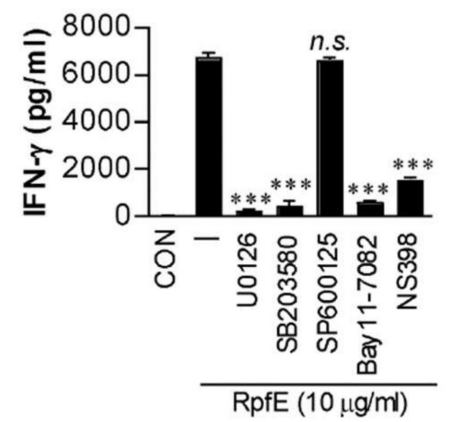

C

E
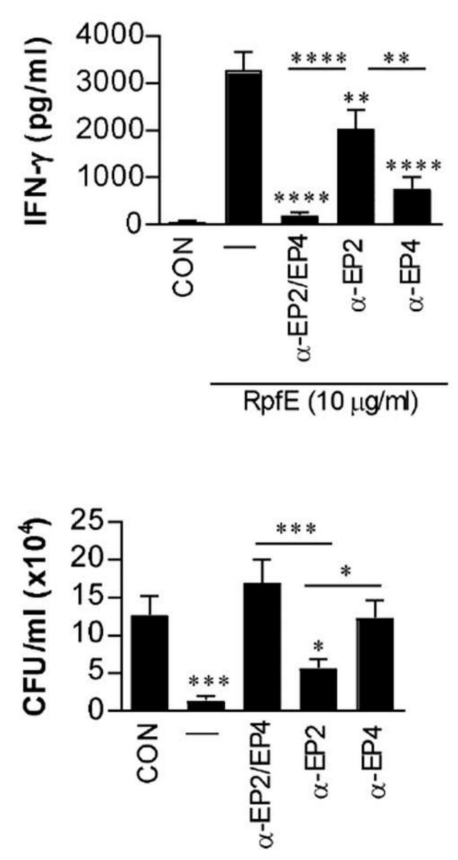

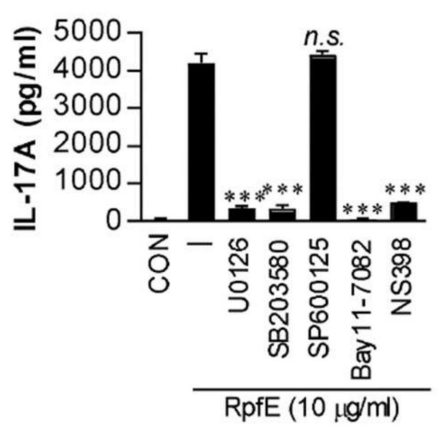

$\operatorname{RpfE}(10 \mu \mathrm{g} / \mathrm{m} \mathrm{l})$

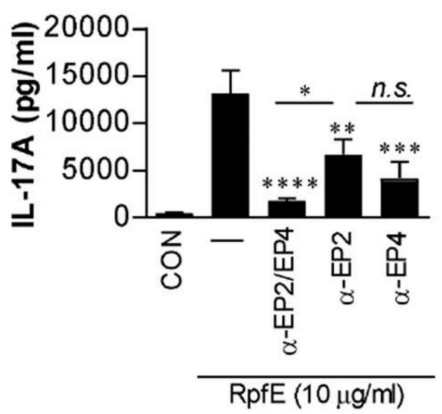

B

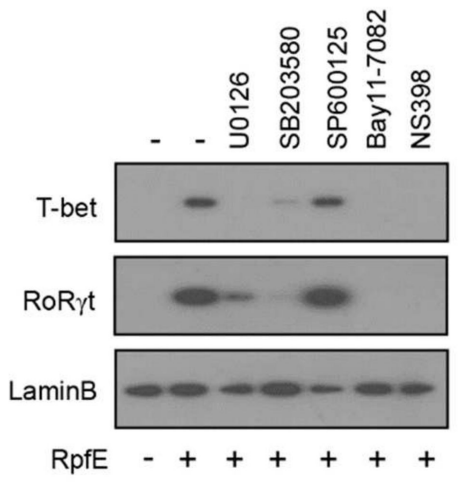

D

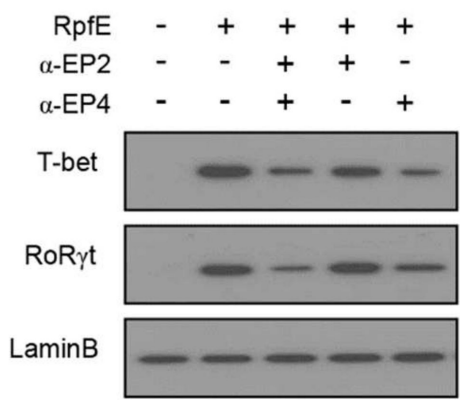

$\operatorname{RpfE}(10 \mu \mathrm{g} / \mathrm{ml})$

Figure 2. Prostaglandin E2 (PGE2) produced by RpfE-activated dendritic cells (DCs) induces Th1/Th17 differentiation via the EP4 receptor. (A,B) $C D 4^{+} \mathrm{T}$ cells were isolated using MACS from Mtb-infected mice splenocytes and co-cultured for $72 \mathrm{~h}$ with dendritic cells (DCs) treated with pharmacological inhibitors for $1 \mathrm{~h}$ prior to treatment with $10 \mu \mathrm{g} / \mathrm{mL}$ RpfE. (A) IFN- $\gamma$ or IL-17A production in T cells co-cultured with RpfE-treated DCs was determined using ELISA in triplicate $(n=3)$. All data are expressed as the mean $\pm \mathrm{SD} ;{ }^{* * *} p<0.001$ for treated samples compared to RpfE-treated DCs co-cultured with $\mathrm{CD}_{4}^{+} \mathrm{T}$ cells; n.s., no significant difference. (B) The levels of T-bet and RoR $\gamma \mathrm{t}$ in T cells were assessed by immunoblotting using specific anti-T-bet and anti-RoR $\gamma \mathrm{t}$ monoclonal antibodies. (C,D) T cells in the presence or absence of neutralizing antibody (anti-EP2, anti-EP4, or anti-EP2/EP4) co-cultured with unstimulated DCs or RpfE-stimulated DCs for 3 days. (C) The cytokine levels in culture supernatants were determined using ELISA. (D) The cell lysates were analyzed by immunoblotting. " $\alpha$ " means neutralization antibody treatment. All data are expressed as the mean $\pm \mathrm{SD} ;{ }^{*} p<0.05,{ }^{* *} p<0.01,{ }^{* * *} p<0.001$ and ${ }^{* * * *} p<0.0001$ for treated samples compared to RpfE-treated DCs co-cultured with CD4 ${ }^{+} \mathrm{T}$ cells; n.s., no significant difference. (E) T cells in the presence or absence of neutralizing antibody (anti-EP2, anti-EP4, or anti-EP2/EP4) activated with unstimulated DCs or RpfE-stimulated DCs at a DC:T cell ratio of 1:10 for 3 days were co-cultured with Mtb-infected bone marrow-derived macrophages (BMDMs). Intracellular Mtb growth in the BMDMs was determined after 3 days. All data are expressed as the mean $\pm \mathrm{SD} ;{ }^{*} p<0.05$ and ${ }^{* * *} p<0.001$ for treated samples compared to infected BMDM co-cultured with activated $\mathrm{CD} 4^{+} \mathrm{T}$ cells by RpfE-treated DCs; $n$.s., no significant difference. 


\subsection{Induction of RpfE-Specific Th1 and Th17 Responses Is Dependent on PGE2 In Vivo}

To investigate whether RpfE could induce Th1 and Th2 responses in vivo in a PGE2dependent manner, which could also contribute to Mtb control, Mtb-infected mice were intranasally administrated six times at two-day intervals with RpfE without an adjuvant. Four weeks after the last treatment, RpfE administration induced a significant reduction in bacterial load in the lungs (Figure 3A). However, bacterial loads in mice injected with NS398 before the first RpfE administration were significantly restored compared to those of the RpfE only-administrated group but were still significantly lower compared to those of the infection control group. Changes in the T-cell phenotypes in mice administrated with RpfE were analyzed using fluorescence-activated cell sorting (FACS). As shown in Figure 3B, the population of IFN- $\gamma^{+}$- and IL- $17^{+}-\mathrm{CD} 4^{+} \mathrm{T}$ cells in the lungs of RpfE-administrated mice, but not in NS398-injected mice, was increased after re-stimulation of lung cells with RpfE. In addition, the number of IL- $17^{+} \mathrm{T}$ cells, but not IFN- $\gamma^{+} \mathrm{T}$ cells, was reduced by NS398 injection (Figure 3B). Cytokines and PGE2 production from the culture supernatants under the same conditions as those in Figure 3B were also determined. As shown in Figure 3C, the production of all cytokines tested and PGE2 were significantly higher in re-stimulated lung cells of the administrated mice with RpfE than in the non-treated mice. However, the production of IL-1 $\beta$, IL-12p70, IL-23p19, IFN- $\gamma$, IL-17A, and PGE2 was significantly suppressed in mice pre-injected with NS398; in particular, the production of IL-23p19, IL-17A, and PGE2 was almost abolished by NS398 injection (Figure 3C). These data suggest that RpfE-induced Th1 and Th17 responses are partially PGE2-dependent, and the Th17 response is more significantly PGE2-dependent than the Th1 response.

\subsection{Optimal Dose of PGE2 Is Essential to Promote Th1/Th17 Differentiation with Strong Bactericidal Activity}

Next, we specifically investigated the PGE2-mediated effect on Th1/Th17 development through networking with other cytokines and the anti-mycobacterial activity of these differentiated T cells. Naïve CD4 ${ }^{+} \mathrm{T}$ cells were cultured in the presence of IL-2 and cytokines related to the differentiation of T cells and then co-cultured with Mtb-infected macrophages. For example, IL- 6 and TGF- $\beta$ were selected for Th17 differentiation and IL-23p19 for maintenance of the Th17 response [38]. As expected, the expression of GATA-3 and T-bet was increased in T cells cultured with IL-2-IL-4 and IL-2-IL-12p70 (Figure 4A), and IL-2-IL-12-cultured T cells, but not IL-2-IL-4-cultured T cells, significantly inhibited Mtb growth in macrophages compared to the infection control (Figure 4B). T cells cultured with IL-2-IL-6-TGF- $\beta$ or IL-2-IL-6-IL-23p19-TGF- $\beta$ expressed only RoR $\gamma$ t (Figure 4A) and did not inhibit Mtb growth (Figure 4B). In contrast, T cells differentiated with IL-2-IL-6IL-23p19-IL-1 $\beta$ expressed both T-bet and RoR $\gamma t$ and significantly inhibited Mtb growth compared to the infection control. The expression of both transcription factors and bacterial growth inhibition were significantly enhanced by PGE2 addition under these conditions (i.e., IL-2-IL-6-IL-23p19-IL-1 $\beta$-PGE2) (Figure 4A,B). The IFN- $\gamma$, IL-17A, and IL-5 levels in the supernatants from the same culture conditions as those in Figure $4 \mathrm{~B}$ were determined. The significant production of IFN- $\gamma$ and IL-17A coincided with culture conditions with T-bet and/or RoR $\gamma$ t expression (Figure 4C), and significant IL-5 production was observed only in GATA-3-expressed conditions (i.e., IL-2-IL-4-cultured T cells). 
A

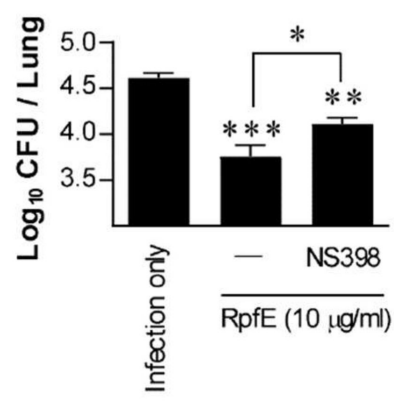

B

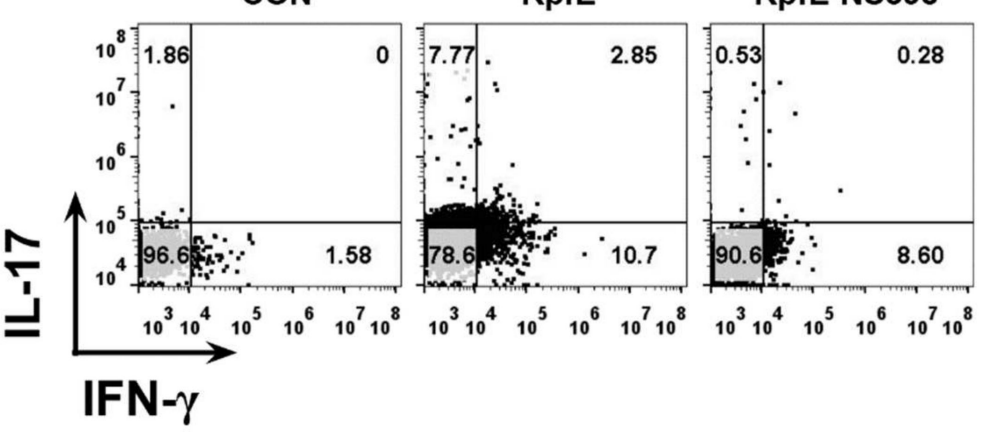

C
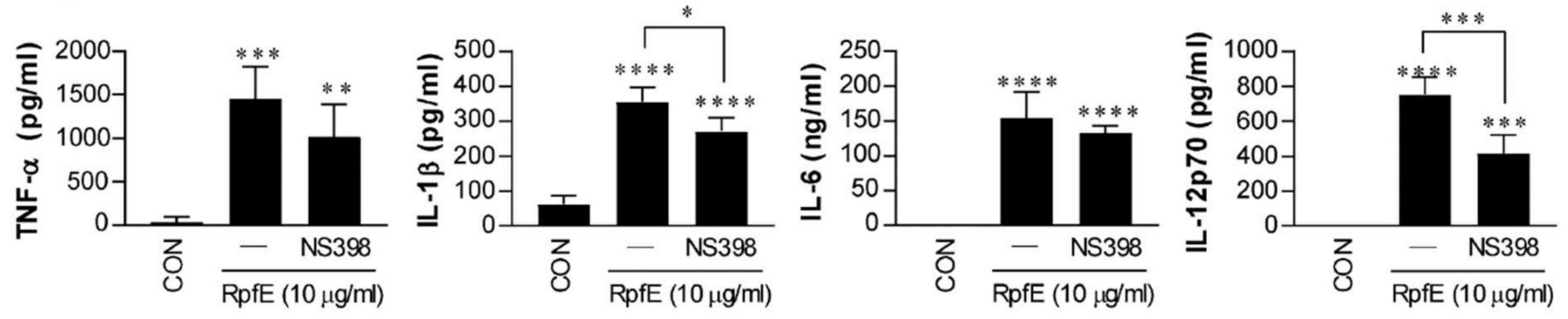
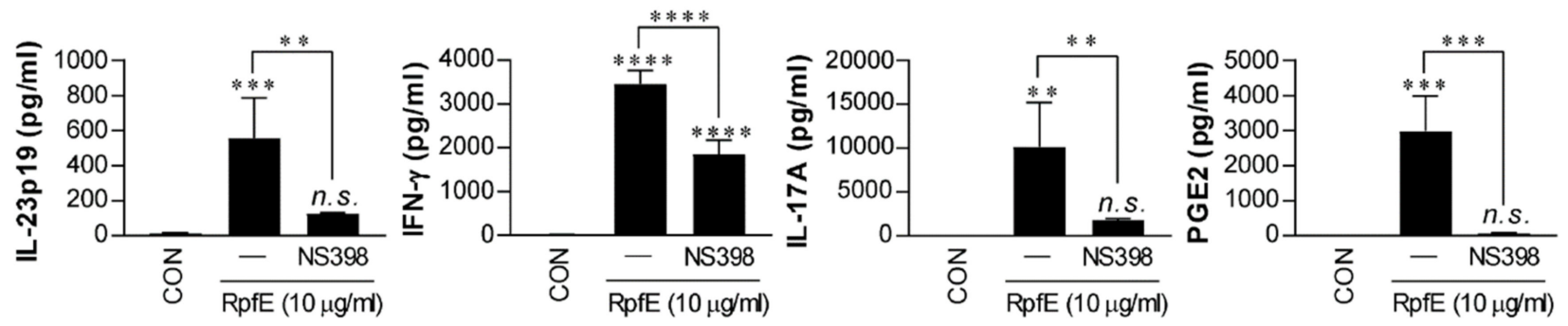

Figure 3. Prostaglandin E2 (PGE2)-dependent induction of RpfE-specific Th1 and Th17 immune responses in vivo. Mtbinfected mice were administrated six times at two-day intervals with RpfE (20 $\mu \mathrm{g})$ by intranasal injection. In the NS398 treated group, RpfE was added at the time of initial administration. (A) Four weeks after the last administration, the lung bacillary burden $(\log 10 \mathrm{CFU})$ was determined. Data are expressed as the mean $\pm \mathrm{SD}$ for 5 mice from each group. n.s.: not significant, ${ }^{*} p<0.05,{ }^{* *} p<0.01$ and ${ }^{* * *} p<0.001$ compared to infection control mice. n.s.: no significant difference, ${ }^{*} p<0.05$ between RpfE- and RpfE+NS398-treated mice. (B) Lung cells were stimulated with RpfE (10 $\mu \mathrm{g} / \mathrm{mL})$, and antigen-specific $\mathrm{CD}^{+} \mathrm{T}$ cells were evaluated for IFN- $\gamma$ and IL-17A secretion by intracellular cytokine staining. (C) Levels of cytokine secreted by lung cells in response to $\operatorname{RpfE}(10 \mu \mathrm{g} / \mathrm{mL})$ stimulation as detected by ELISA in all treatment groups. Data are expressed as the mean \pm SD for 5 mice from each group. n.s.: no significant difference, ${ }^{* *} p<0.01,{ }^{* * *} p<0.001$ and ${ }^{* * * *} p<0.0001$ compared to infection control mice. n.s.: no significant difference, ${ }^{*} p<0.05,{ }^{* *} p<0.01,{ }^{* * *} p<0.001$ and **** $p<0.0001$ between RpfE- and RpfE+NS398-treated mice. 


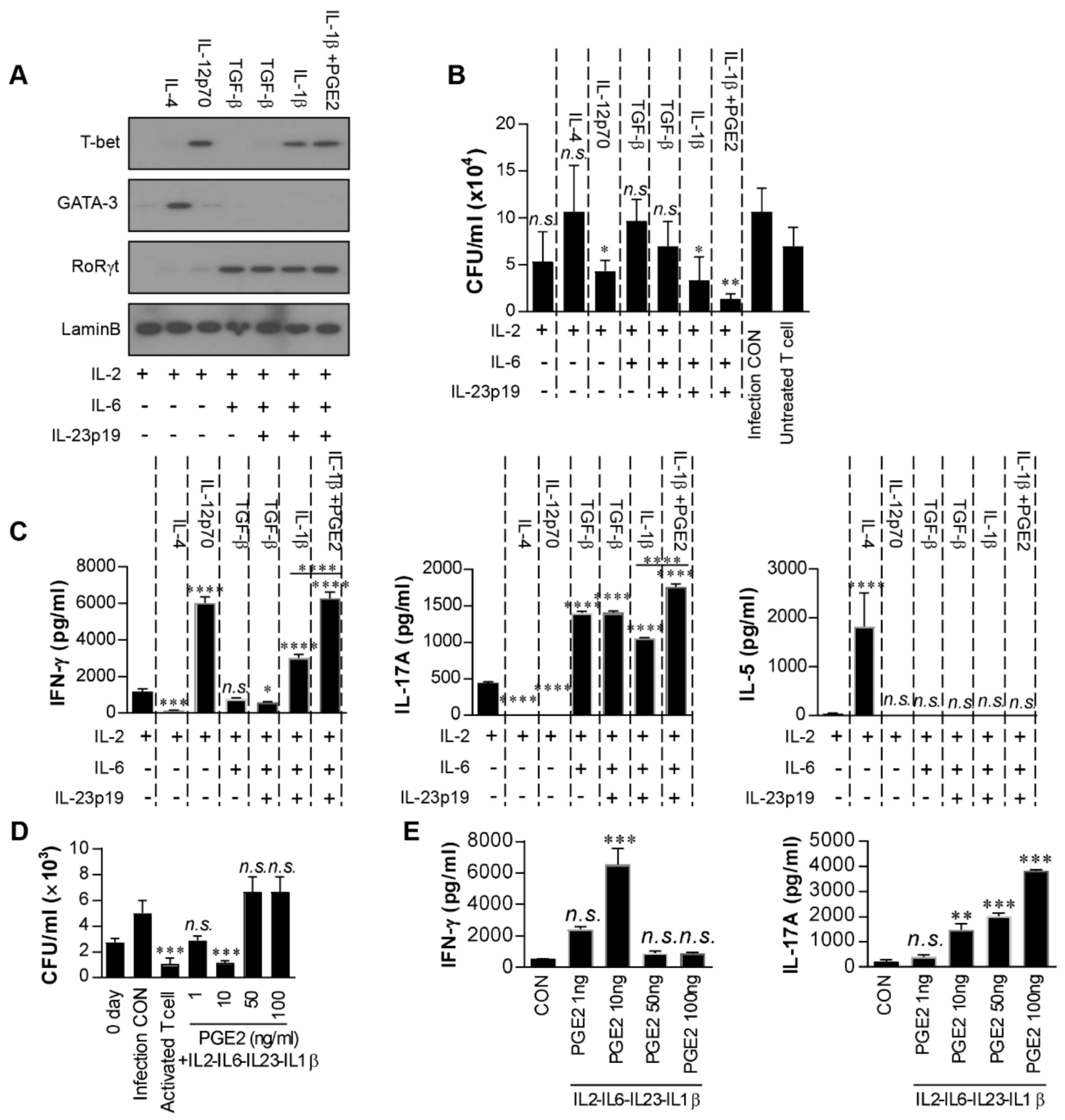

Figure 4. Low-dose prostaglandin E2 (PGE2) promotes Th1/Th17 differentiation in vitro. Naïve CD4 ${ }^{+} \mathrm{T}$ cells $\left(1 \times 10^{6}\right)$ were cultured with cytokines ( $5 \mathrm{ng} / \mathrm{mL}$ IL-2; $25 \mathrm{ng} / \mathrm{mL}$ IL-4; $5 \mathrm{ng} / \mathrm{mL}$ IL-12; $25 \mathrm{ng} / \mathrm{mL}$ IL-6; $250 \mathrm{ng} / \mathrm{mL} \mathrm{TGF}-\beta ; 50 \mathrm{ng} / \mathrm{mL}$ IL-23; $10 \mathrm{ng} / \mathrm{mL}$ IL-1 $\beta ; 5 \mathrm{ng} / \mathrm{mL}$ PGE2) in 24-well culture plates coated with anti-CD3 antibodies $(2 \mu \mathrm{g} / \mathrm{mL})$ for 5 days. (A) The levels of T-bet, GATA-3, and RoR $\gamma t$ in differentiated T cells induced by each combination of cytokines were assessed by immunoblotting. (B) Differentiated T cells induced by each combination of cytokines were co-cultured with Mycobacterium tuberculosis (Mtb)-infected bone marrow-derived macrophages (BMDMs). Intracellular Mtb growth in the BMDMs was determined after 3 days. All data are expressed as the mean $\pm \mathrm{SD} ;{ }^{*} p<0.05$ and ${ }^{* *} p<0.01$ for treated samples compared to infection control; n.s., no significant difference. (C) The quantities of IFN- $\gamma$, IL-17A, and IL-5 in the culture supernatants were determined using ELISA. (D,E) T cells were generated by stimulating naïve T cells with $5 \mathrm{ng} / \mathrm{mL}$ IL-2, $25 \mathrm{ng} / \mathrm{mL}$ IL-6, $250 \mathrm{ng} / \mathrm{mL}$ TGF- $\beta, 50 \mathrm{ng} / \mathrm{mL}$ IL-23, $10 \mathrm{ng} / \mathrm{mL}$ IL-1 $\beta$ and PGE2 (1, 10, 50 or $100 \mathrm{ng} / \mathrm{mL})$ for $96 \mathrm{~h}$. All data are expressed as the mean $\pm \mathrm{SD} ;{ }^{*} p<0.05,{ }^{* * *} p<0.001$ and ${ }^{* * *} p<0.0001$ for treated samples compared to IL-2 treated T cell; $n$.s., no significant difference. (D) These T cells were co-cultured with Mtb-infected BMDMs. Intracellular Mtb growth in the BMDMs was determined after 3 days. Activated T cell was positive control and T cells activated by RpfE-matured DCs. Data are the mean \pm SD from three independent experiments; ${ }^{* * *} p<0.001$ compared to infection control. n.s.: no significant difference. (E) The culture supernatants were determined using ELISA. Data are the mean \pm SD from three independent experiments; ${ }^{* *} p<0.01$ and ${ }^{* *} p<0.001$ vs. appropriate controls. $n$.s.: no significant difference. 
PGE2 exerts both immunosuppressive and pro-inflammatory roles in T-cell responses in a PGE2 concentration-dependent manner $[39,40]$. Therefore, we determined the antibacterial activity of these T cells differentiated with IL-2, IL-6, IL-23p19, IL-1 $\beta$, and PGE2 (1-100 $\mathrm{ng} / \mathrm{mL})$ in Mtb-infected macrophages. T cells differentiated in the presence of $10 \mathrm{ng} / \mathrm{mL}$ PGE2 significantly inhibited Mtb growth compared to the infection control, and their bactericidal activity was comparable with that of $\mathrm{T}$ cells activated by RpfE-matured DCs (Figure 4D). In contrast, T cells activated with $1 \mathrm{ng} / \mathrm{mL}$ PGE2 did not significantly inhibit Mtb growth compared to the infection control, and T cells developed with a high concentration of PGE2 $(>50 \mathrm{ng} / \mathrm{mL})$ did not induce a bactericidal activity in macrophages. Under the same conditions as in Figure $4 \mathrm{D}$, significant IFN- $\gamma$ was produced in the presence of $10 \mathrm{ng} / \mathrm{mL}$ PGE2 but not at higher concentrations; in contrast, IL-17A was produced in a PGE2 dose-dependent manner (Figure 4E). In fact, COX2 expression was significantly induced in macrophages with avirulent Mtb H37Ra but not Mtb H37Rv, and the addition of PGE2 (10-100 $\mathrm{ng} / \mathrm{mL}$ ) in Mtb-infected macrophages did not inhibit bacterial growth (Supplementary Materials, Figure S1). These data suggest that IFN- $\gamma$ and optimal IL-17 are required for $\mathrm{T}$ cell differentiation with strong bactericidal activity, and differentiation is induced in these $\mathrm{T}$ cells by an optimal concentration of PGE2. Taken together, these results indicate that RpfE-matured DCs produce PGE2 that leads to Th1 and Th17 development with the best anti-mycobacterial activity.

\section{Discussion}

A previous study revealed that RpfE-matured DCs stimulate naïve T cells and antigenspecific T cells to produce IFN- $\gamma$ and IL-17 [6]. However, the underlying mechanism inducing the Th1- and Th17-immune responses remains unclear. Here, we report that PGE2 is produced by RpfE-activated DCs via the MAPK/NF-KB/COX2 signaling pathway, resulting in Th1/Th17 cell differentiation with mycobactericidal activity mainly via the EP4 receptor.

To elicit Th1-cell-based immunity is based on evidence from various animal models that a strong IFN- $\gamma$-mediated Th1 immune response is the primary protective mechanism of anti-TB immunity [41-46]. However, an IFN- $\gamma$ response is not an optimal correlate of protection [47-49] because IFN- $\gamma$ alone is insufficient to control Mtb infection [50]. Previous studies have demonstrated that antigens that do not elicit Th1 responses uniformly fail to protect against $\mathrm{Mtb}$, but not all proteins that induce robust Th1 responses after vaccination provide considerable protection [46,51-53]. In addition, Th17 cells also contribute to protective TB immunity in mice [54-56], cynomolgus macaques [57], and rhesus macaques [58]. Although the role of Th17 cells in human patients appears ambiguous [59,60], early Th17 responses are suppressed in Mtb-infected patients as compared to healthy controls [61]. Therefore, the identification of a mechanism inducing RpfE-mediated Th1 and Th17 responses is important to understand subunit vaccine-induced protective responses.

PGE2 regulates a multitude of functions in cell activation/suppression, differentiation, maturation, homeostatic, and inflammatory responses. Focusing on the relationship between PGE2 and T lymphocytes, in the past, PGE2 produced by APCs inhibited the production of IL-2 and IFN- $\gamma$ and suppressed the proliferation of murine and human T cells in vitro $[62,63]$. However, a previous study demonstrated that exogenously added lowdose PGE2 potentiates Th1 and Th17 responses and aids in T-cell proliferation [14,35,36], which are related to the underlying mechanisms of various immune diseases. Virulent Mtb inhibits COX2 expression in macrophages, resulting in inhibition of the PGE2-inducing apoptotic response and prevention of necrotic response [64]. In this study, we also found that avirulent Mtb H37Ra, but not H37Rv strain, induced significant COX2 expression in DCs. However, there are no reports on the mycobacterial components regulating PGE2 or COX2 production in APCs. Interestingly, our data suggest that RpfE-activated DCs produce PGE2 via COX2 expression, indicating that the NS398 suppressed the RpfE-mediated PGE2 production. The NF- $\mathrm{KB}$ and MAPK pathways have been reported to induce COX2 expression in activated macrophages [65]. Furthermore, activated NF- $\mathrm{kB}$ translocates into 
the nucleus and then secretes Th1/Th17-related cytokines, such as IL-1 $\beta$, IL-6, IL-12p70, and IL-23p19 [6]. Therefore, our data support that RpfE-activated DCs produce PGE2 through the MAPK/NF- $\mathrm{KB} / \mathrm{COX} 2$ signaling pathway and that PGE2 may be a key factor inducing the Th1/Th17 response (Figures 1-3).

The heterogeneous effects of PGE2 are reflected by the existence of four different PGE2 receptors, designated EP1, EP2, EP3, and EP4, among which EP2 represents low-affinity receptors, whereas EP4 requires significantly lower concentrations of PGE2 for effective signaling [40]. Therefore, EP2 and EP4 signaling is triggered by different concentrations of PGE2, which differs in duration. EP4 signaling is rapidly desensitized following its interaction with PGE2, whereas EP2 is resistant to ligand-induced desensitization, indicating its ability to mediate PGE2 functions over prolonged periods of time and at later time points of inflammation [66]. Kaul et al. reported that EP2-deficient mice showed increased susceptibility to Mtb infection [28]. Previous studies have demonstrated that low-dose PGE2 potentiates Th1 and Th17 responses of mouse T cells in vitro through the EP2 and EP4 receptors [39,67]. In the present study, our results support that PGE2 produced by RpfE-stimulated DCs induces Th1 and Th17 responses mainly via the EP4 receptor and minor EP2 receptor. Blocking EP4 on T cells led to a more profound inhibition of IFN- $\gamma$ and IL-17 production and abrogation of RpfE-mediated Mtb growth inhibition (Figure 2). Furthermore, we also demonstrated that mice administered nasally with RpfE showed a significant reduction in bacterial load in the lung, and these effects of RpfE were partially lost by injection of NS398 before RpfE administration (Figure 3).

Considering the substantial contributions of Th differentiation in the inhibition of Mtb growth, it is important to reveal the cytokine networks that regulate Th differentiation from naïve $\mathrm{CD}^{+} \mathrm{T}$ cells. To do this, it is essential to establish a Th differential system using various related cytokines. Therefore, we conducted an experiment using an in vitro naïve T-cell differentiation system to confirm whether PGE2 affects T-cell differentiation (Figure 4). Th1 polarization is primarily driven by IL-12 and IFN- $\gamma$, while Th2 polarization is primarily driven by IL-4. These cytokine signals via STAT4, STAT1, and STAT6 directly control the transcription factors T-bet and GATA3, which, in turn, determine Th1 and Th2 differentiation, respectively [68]. Th1 cells produce IFN- $\gamma$, which facilitates their differentiation while inhibiting IL-4-mediated Th2 differentiation [69]. Reciprocally, Th2 cells produce IL-4 and IL-10, which strongly inhibit IL-12/IFN- $\gamma$-driven Th1 differentiation. In the present study, we confirmed that T cells cultured with IL-2-IL-12 and IL-2-IL-4 differentiated into Th1 and Th2 cells (Figure 4). The Th17 differentiation of naïve T cells is initiated by IL- 6 and TGF- $\beta$ [70-73]. In addition, IL-23 and IL-21 are thought to be key cytokines involved in the maturation and/or maintenance of Th17 cells [74-76]. IL-6, IL-21, and IL-23 activate STAT3, which is essential for Th17 differentiation. STAT3 plays a critical role in the induction of the orphan nuclear receptor RoR $\gamma \mathrm{t}$, which directs Th17 cell differentiation by inducing the IL-23 receptor. Our data suggest that $\mathrm{T}$ cells cultured in the presence of IL-2-IL-6-TGF- $\beta$ differentiate into Th17 cells, but not Th1 cells, irrespective of the presence of IL-23. Although TGF- $\beta$ is clearly required for the generation of Th17 cells, TGF- $\beta$ indirectly favors the expansion of Th17 cells through the inhibition of Th1 cell development [77]. In contrast, $\mathrm{CD}^{+} \mathrm{T}$ cells that develop in the presence of IL- $1 \beta$ can develop into IL-17-and IFN- $\gamma$-secreting cells [78]. In this study, T cells in the presence of IL-2, IL-6, and TGF- $\beta$ with or without IL-23p19 expressed the Th17 transcription factor but not the Th1 transcription factor. However, both the transcription factors for Th1 and Th17 differentiation were expressed when IL-1 $\beta$, but not TGF- $\beta$, was added under these culture conditions (i.e., IL-2-IL-6-IL-23p19-IL-1 $\beta$ ), and both IFN- $\gamma$ and IL-17 were produced by these $\mathrm{T}$ cells. The $\mathrm{T}$ cells differentiated in the presence of PGE2 (i.e., IL-2IL-6-IL-23p19-IL-1 $\beta$-PGE2) produced significantly higher levels of IFN- $\gamma$ and IL-17 than those in the absence of PGE2 (Figure 4C) and showed the most prominent inhibition of Mtb growth in macrophages (Figure 4B). Furthermore, the optimal concentration of PGE2 in differentiated T cells was critical to elicit the best bactericidal effects (Figure 4D). In a previous study, high concentrations of PGE2 favored IL-17 production and down- 
modulation of IFN- $\gamma$ production [79], but low concentrations of PGE2 potentiated Th1 and Th17 differentiation [36]. Therefore, it is suggested that PGE2 induces Th1/Th17 cell differentiation at an optimal concentration, which enhances the killing effect on $\mathrm{Mtb}$.

In conclusion, our study shed light on a paradox in which the important role of PGE2 in mediating inflammation remains controversial with respect to its effects on $\mathrm{T}$ helper cell function and cytokine production. Our findings also highlights that RpfE-activated DCs produce an optimal amount of PGE2 to induce the differentiation of naive $\mathrm{T}$ cells into Th1/Th17 cells with strong bactericidal activity. In a recent study, the importance of Th1 and Th17 in the effective control of Mtb has been emphasized in mice and humans [80,81]. In addition, our previous study also published the highest correlation between IFN- $\gamma /$ IL-17 co-producing $\mathrm{CD}^{+} \mathrm{T}$ cells and Mtb growth inhibition [46]. Therefore, the results provide that RpfE, which can induce Th1/Th17 by producing the optimal dose of PGE2, has potential Mtb vaccine candidate.

\section{Materials and Methods}

\subsection{Animals}

Specific pathogen-free female C57BL/ $6\left(\mathrm{H}-2 \mathrm{~K}^{\mathrm{b}}\right.$ and I- $\left.\mathrm{A}^{\mathrm{b}}\right)$ mice were purchased from the Jackson Laboratory (Bar Harbor, ME, USA) at 5-6 weeks of age and were maintained under barrier conditions in a biohazard animal room at the Medical Research Center of Chungnam National University, Daejeon, Korea. The animals were fed a sterile commercial mouse diet and were provided water Ad libitum. All animal experiments complied with the ethical and experimental regulations for animal care of Chungnam National University (CNU-00284).

\subsection{Cell Preparation}

Murine bone marrow-derived DCs (BMDCs) were generated, cultured, and purified as described previously [82]. Bone marrow-derived macrophages (BMDMs) were prepared using recombinant M-CSF (CreaGene, Gyeonggi, Korea), as previously described [82]. Briefly, bone marrow cells isolated from C57BL/ 6 mice were lysed with red blood cell (RBC)lysing buffer (ammonium chloride $4.15 \mathrm{~g} / 500 \mathrm{~mL}, 0.01 \mathrm{M}$ Tris- $\mathrm{HCl}$ buffer $\mathrm{pH}$ [7.5 \pm 0.2$]$ ) and washed with RPMI 1640 medium. The obtained cells were plated in 6-well culture plates $\left(10^{6}\right.$ cells $/ \mathrm{mL}, 3 \mathrm{~mL} /$ well $)$ and cultured at $37{ }^{\circ} \mathrm{C}$ in the presence of $5 \% \mathrm{CO}_{2}$ in RPMI 1640 media supplemented with $100 \mathrm{unit} / \mathrm{mL}$ penicillin/streptomycin (Lonza, Basel, Switzerland), 10\% fetal bovine serum (Lonza, Basel, Switzerland), $50 \mu \mathrm{M}$ mercaptoethanol (Lonza, Basel, Switzerland), $0.1 \mathrm{mM}$ non-essential amino acids (Lonza, Basel, Switzerland), $1 \mathrm{mM}$ sodium pyruvate (Sigma, St. Louis, MO, USA), $20 \mathrm{ng} / \mathrm{mL}$ GM-CSF (CreaGene, Gyeonggi, Korea), and $10 \mathrm{ng} / \mathrm{mL}$ IL-4 (for BMDCs) or $20 \mathrm{ng} / \mathrm{mL}$ M-CSF (for BMDMs).

Age- and sex-matched C57BL/6 mice were infected with Mtb H37Ra ATCC 25177. Briefly, following anesthetization using a xylazine:zoletil (9:1) mixture, 12 mice per group were intratracheally infected with $50 \mu \mathrm{L}$ of suspensions to achieve initial infectious doses of 10,000 CFU of H37Ra per mouse lung. Five to six mice were sacrificed at eight weeks post-infection, and their spleens were isolated under sterile conditions. Then, the spleen cells and aggregates were filtered through a $40 \mu \mathrm{m}$ cell strainer in Dulbecco's phosphatebuffered saline (PBS) using a sterile $1 \mathrm{~mL}$ syringe. The erythrocytes were lysed using RBC lysis buffer $\left(90 \mathrm{~mL} 0.16 \mathrm{M} \mathrm{NH}_{4}\right.$ and $10 \mathrm{~mL}$ of $0.17 \mathrm{M}$ Tris [pH 7.65]) for $2 \mathrm{~min}$ at room temperature. Total spleen $\left(1 \times 10^{7}\right.$ cells $/$ well $)$ from H37Ra-infected mice were stimulated using RpfE $(10 \mu \mathrm{g} / \mathrm{mL})$.

Mtb-infected mice were vaccinated six times at two-day intervals with RpfE (20 $\mu \mathrm{g})$ by intranasal injection following anesthesia with an intraperitoneal injection of xylazine:zoletil (9:1). In the NS398 (Abcam, Cambridge, UK) treated group, RpfE was added at the time of initial administration. Four weeks after the last vaccination, the mice were euthanized. The lungs were isolated under sterile conditions. These organs were cut into $0.5 \mathrm{~cm}$ pieces and agitated in $5 \mathrm{~mL}$ of cellular dissociation buffer (RPMI medium containing $0.1 \%$ collagenase type IV (Worthington Biochemical Corporation, Lakewood, NJ, USA), $1 \mathrm{mM} \mathrm{CaCl}_{2}$, and 
$1 \mathrm{mM} \mathrm{MgCl} 2$ for $15 \mathrm{~min}$ at $37^{\circ} \mathrm{C}$. Then, the lung cells and aggregates were filtered through a $40 \mu \mathrm{m}$ cell strainer in Dulbecco's PBS using a sterile $1 \mathrm{~mL}$ syringe. Erythrocytes were lysed using RBC lysis buffer for $2 \mathrm{~min}$ at room temperature. Total lung cells $\left(1 \times 10^{7}\right.$ cells /well $)$ from RpfE-vaccinated mice were stimulated using RpfE $(10 \mu \mathrm{g} / \mathrm{mL})$.

$\mathrm{CD}^{+} \mathrm{T}$ cells were isolated from the spleens of non-infected mice using a MACS LS CD4-positive selection column. Purified CD4 ${ }^{+} \mathrm{T}$ cells $\left(5 \times 10^{6}\right.$ cells/well $)$ were co-cultured with DC subsets $\left(5 \times 10^{5}\right.$ cells/well) and stimulated with RpfE. Cells were collected at $48 \mathrm{~h}$ for western blot analysis of T-bet, RoR $\gamma \mathrm{t}$, and GATA-3 levels. The supernatants were collected at $72 \mathrm{~h}$, and the cytokine levels were determined using ELISA.

\subsection{Bacterial Counts}

Adherent BMDMs $\left(2 \times 10^{4}\right.$ cells/well) were washed twice in PBS and infected in triplicate with $\mathrm{Mtb}\left(2 \times 10^{4}\right.$ bacilli/well). Tubercle bacilli and macrophages were incubated for $4 \mathrm{~h}$. Then, the infected BMDMs were treated with amikacin $(200 \mu \mathrm{g} / \mathrm{mL})$ for $2 \mathrm{~h}$. After $2 \mathrm{~h}$, the monolayers were washed to remove extracellular bacilli. Two different types of CFU measurements in infected macrophages were performed. First, a previously prepared mixture was added to each well, and the plate was incubated for 3 days. The mixture consisted of antigen-activated DCs co-cultured with $\mathrm{CD}^{+}$sorted T cells at a DC:T cell ratio of 1:10 for 3 days. These $\mathrm{CD} 4^{+} \mathrm{T}$ cells were pre-incubated with neutralizing antibodies against EP2 (R\&D Systems, Minneapolis, MN, USA) (200 ng/mL), EP4 (R\&D Systems) $(200 \mathrm{ng} / \mathrm{mL})$, or EP2/EP4 $(200 \mathrm{ng} / \mathrm{mL})$ for $2 \mathrm{~h}$ at a DC:T cell ratio of 1:10 for 3 days. The DCactivating antigens were $\operatorname{RpfE}(10 \mu \mathrm{g} / \mathrm{mL})$. Second, the infected BMDMs were co-cultured with differentiated $\mathrm{T}$ cells incubated with cytokines. All cytokine used were purchased from R\&D Systems. The differentiated T cells were naïve CD4 ${ }^{+} \mathrm{T}$ cells $\left(1 \times 10^{6}\right)$ cultured with each cytokine ( $5 \mathrm{ng} / \mathrm{mL}$ IL-2, $25 \mathrm{ng} / \mathrm{mL}$ IL-4, $5 \mathrm{ng} / \mathrm{mL}$ IL-12, $25 \mathrm{ng} / \mathrm{mL}$ IL-6, $250 \mathrm{ng} / \mathrm{mL}$ TGF- $\beta, 50 \mathrm{ng} / \mathrm{mL}$ IL-23, $10 \mathrm{ng} / \mathrm{mL}$ IL-1 $\beta$, and $5 \mathrm{ng} / \mathrm{mL}$ PGE2) in 24-well culture plates coated with anti-CD3 antibodies $(2 \mu \mathrm{g} / \mathrm{mL})$ for 5 days. The number of ingested and internalized Mtb by BMDMs was calculated by lysing the infected cells from one of the wells in distilled water. The Tubercle bacilli counts of the inoculum were then checked by serial dilution and plating on 7H10 agar with 10\% Middlebrook OADC supplement (Difco, Detroit, MI, USA). The plates were incubated at $37^{\circ} \mathrm{C}$ for three weeks. At the end of the three-week period, plates were taken out, and colony-forming units (CFUs) were calculated from the number of Mtb colonies.

Four weeks after the last immunization, the lungs were dissected from the infected mice and homogenized. The number of viable bacteria was determined by plating serial dilutions of the lung homogenates onto Middlebrook 7H10 agar (Difco Laboratories, Detroit, MI, USA) supplemented with 10\% OADC (Difco Laboratories) and amphotericin B (Sigma-Aldrich, St. Louis, MO, USA). Colonies were counted after four weeks of incubation at $37^{\circ} \mathrm{C}$.

\subsection{Intracellular Cytokine Staining}

Four weeks after the last immunization, the mice were euthanized by $\mathrm{CO}_{2}$ asphyxiation, and single-cell suspensions $\left(1 \times 10^{6}\right.$ cells) from immunized mice were re-stimulated with $\operatorname{RpfE}(10 \mu \mathrm{g} / \mathrm{mL})$ at $37^{\circ} \mathrm{C}$ for $12 \mathrm{~h}$ in the presence of both GolgiPlug and GolgiStop (BD Biosciences, Franklin Lakes, NJ, USA). PBS-washed cells were blocked with anti$\mathrm{CD} 16 / 32$ antibody (BD Biosciences) at $4{ }^{\circ} \mathrm{C}$ for $20 \mathrm{~min}$. The cells were then surface stained with Brilliant Violet (BV) 605-conjugated anti-CD4 antibody (BD Biosciences) at $4{ }^{\circ} \mathrm{C}$ for $30 \mathrm{~min}$ and washed three times with PBS. These cells were fixed and permeabilized with the Cytofix/Cytoperm kit (BD Biosciences) at $4{ }^{\circ} \mathrm{C}$ for $30 \mathrm{~min}$ following the manufacturer's instructions. Cells were then washed three times with Perm/Wash (BD Biosciences) and stained intracellularly with PE-conjugated anti-IFN- $\gamma$ (BD Biosciences) and FITCconjugated anti-IL-17 (BD Biosciences) at $4{ }^{\circ} \mathrm{C}$ for $30 \mathrm{~min}$. After washing three times with Perm/Wash, the cells were fixed using IC fixation buffer (eBioscience, San Diego, CA, USA). Intracellular cytokine levels were detected using the software program Novocyte 
(Acea Biosciences, San Diego, CA, USA) and analyzed using the software program FlowJo (Treestar, Inc., San Carlos, CA, USA).

\subsection{Cytokine Measurement}

Sandwich enzyme-linked immunosorbent assay (ELISA) was used to determine the levels of PGE2, IL-1 $\beta$, TNF- $\alpha$, IFN- $\gamma$, IL-17A, IL-23p19, IL-12p70, and IL-10 in the culture supernatants, as previously described [83]. These cytokine assays were performed as recommended by the antibody manufacturers (eBioscience and BD Biosciences).

\subsection{Immunoblotting Analysis}

Stimulated DCs or differentiated T cells were lysed in $100 \mu \mathrm{L}$ of lysis buffer containing $50 \mathrm{mM}$ Tris- $\mathrm{HCl}$ (pH 7.5), $150 \mathrm{mM} \mathrm{NaCl}, 1 \%$ Triton-X100, $1 \mathrm{mM}$ EDTA, $50 \mathrm{mM} \mathrm{NaF}$, $30 \mathrm{mM} \mathrm{Na}_{4} \mathrm{PO}_{7}, 1 \mathrm{mM}$ phenylmethanesulfonyl fluoride, $2 \mu \mathrm{g} / \mathrm{mL}$ aprotinin, and $1 \mathrm{mM}$ pervanadate. Immunoblotting was performed as previously described [83]. Epitopes of the target proteins, including COX2, NF- $\mathrm{kB}$, T-bet, and RoR $\gamma \mathrm{t}$, were labeled using specific antibodies, and the bands were visualized using the ECL Advance Kit (GE Healthcare, Little Chalfont, UK).

\subsection{Nuclear Extract Preparation}

Nuclear extracts were prepared by first treating stimulated DCs or differentiated T cells with $100 \mu \mathrm{L}$ of lysis buffer (10 mM HEPES [pH 7.9], $10 \mathrm{mM} \mathrm{KCl}, 0.1 \mathrm{mM}$ EDTA, $0.5 \%$ Nonidet P- $40,1 \mathrm{mM}$ dithiothreitol, and $0.5 \mathrm{mM}$ PMSF) on ice for $10 \mathrm{~min}$. The lysates were centrifuged at $4000 \mathrm{rpm}$ for $5 \mathrm{~min}$, and the pellet was resuspended in $100 \mu \mathrm{L}$ of extraction buffer (20 mM HEPES [pH 7.9], $400 \mathrm{mM} \mathrm{NaCl}, 1 \mathrm{mM}$ EDTA, $1 \mathrm{mM}$ DTT, and 1 $\mathrm{mM}$ PMSF) and incubated on ice for $30 \mathrm{~min}$. Following centrifugation at 12,000 rpm for 10 min, the supernatant containing the nuclear extracts was collected and stored at $-80^{\circ} \mathrm{C}$ until use.

\subsection{Treatment of DCs with Pharmacological Inhibitors of Signaling Pathways}

All pharmacological inhibitors used were purchased from Calbiochem (San Diego, CA, USA). Dimethyl sulfoxide (Sigma) was added to the cultures to a final concentration of $0.1 \%(v / v)$ as solvent control. DCs were washed using PBS and pretreated with inhibitors in RPMI 1640 medium containing glutamine for $1 \mathrm{~h}$ prior to treatment with RpfE for $24 \mathrm{~h}$. The inhibitors were used at the following concentrations as determined by careful titration: U0126 $(10 \mu \mathrm{M})$, SB203580 $(20 \mu \mathrm{M})$, SP600125 $(10 \mu \mathrm{M})$, Bay11-7082 $(20 \mu \mathrm{M})$, and NS398 $(10 \mu \mathrm{M})$. The viability of the DCs was assessed using an MTT assay.

\subsection{Statistical Analysis}

All experiments were repeated at least three times, with consistent results. Significant differences between two groups were determined by unpaired Student's $t$-test, or those among more than three groups were evaluated with one-way ANOVA followed by Tukey's multiple comparison test using GraphPad Prism Software, version 4.03 (GraphPad Software Inc., San Diego, CA, USA). Data are expressed as the mean \pm standard deviation (SD). Values with ${ }^{*} p<0.05,{ }^{* *} p<0.01$, and ${ }^{* * *} p<0.001$ were considered statistically significant.

Supplementary Materials: The following are available online at https:/ /www.mdpi.com/article/10 $.3390 /$ ijms22147535/s1. Figure S1: Confirmation of prostaglandin E2 (PGE2) production in infected macrophages and the inhibitory effect of PGE2 on Mycobacterium tuberculosis (Mtb) growth.

Author Contributions: Conceptualization, H.-S.P., H.-G.C. and H.-J.K.; Methodology, H.-S.P., H.G.C.; Software, K.-I.L.; Validation, Y.-W.B.; Formal Analysis, H.-G.C.; Investigation, H.-S.P., S.C., Y.-W.B., K.-I.L. and H.-G.C.; Resources, S.C.; Data Curation, H.-S.P. and H.-G.C.; Writing-Original Draft Preparation, H.-G.C. and H.-J.K.; Writing-Review \& Editing, H.-S.P., H.-G.C. and H.-J.K.; Visualization, H.-S.P. and H.-G.C.; Supervision, H.-J.K.; Project Administration, H.-J.K.; Funding 
Acquisition, H.-G.C. and H.-J.K. All authors have read and agreed to the published version of the manuscript.

Funding: This study was supported by the Basic Science Research Program through the National Research Foundation of Korea (NRF) funded by the Ministry of Science, ICT, and Future Planning (2018R1C1B6007518 and 2020R1A2C1008826).

Institutional Review Board Statement: The study was conducted in accordance with the Institutional Research Ethics Committee of Chungnam National University (approval number: CNU-00284) and the guidelines of the Food and Drug Administration.

Informed Consent Statement: Not applicable.

Data Availability Statement: All data are contained within the manuscript.

Conflicts of Interest: The authors declare no conflict of interest.

\section{References}

1. Aagaard, C.; Dietrich, J.; Doherty, M.; Andersen, P. TB vaccines: Current status and future perspectives. Immunol. Cell Biol. 2009, 87, 279-286. [CrossRef] [PubMed]

2. Al-Kassimi, F.A.; Al-Hajjaj, M.S.; Al-Orainey, I.O.; Bamgboye, E.A. Does the protective effect of neonatal BCG correlate with vaccine-induced tuberculin reaction? Am. J. Respir. Crit. Care Med. 1995, 152 Pt 1, 1575-1578. [CrossRef]

3. Sterne, J.A.; Rodrigues, L.C.; Guedes, I.N. Does the efficacy of BCG decline with time since vaccination? Int. J. Tuberc. Lung Dis. 1998, 2, 200-207. [PubMed]

4. Brewer, T.F. Preventing tuberculosis with bacillus Calmette-Guerin vaccine: A meta-analysis of the literature. Clin. Infect. Dis. 2000, 31 (Suppl. 3), S64-S67. [CrossRef]

5. Gowthaman, U.; Singh, V.; Zeng, W.; Jain, S.; Siddiqui, K.F.; Chodisetti, S.B.; Gurram, R.K.; Parihar, P.; Gupta, P.; Gupta, U.D.; et al. Promiscuous Peptide of $16 \mathrm{kDa}$ Antigen Linked to Pam2Cys Protects Against Mycobacterium tuberculosis by Evoking Enduring Memory T-Cell Response. J. Infect. Dis. 2011, 204, 1328-1338. [CrossRef]

6. Choi, H.G.; Kim, W.S.; Back, Y.W.; Kim, H.; Kwon, K.W.; Kim, J.S.; Kim, H.J. Mycobacterium tuberculosis RpfE promotes simultaneous Th1- and Th17-type T-cell immunity via TLR4-dependent maturation of dendritic cells. Eur. J. Immunol. 2015, 45, $1957-1971$. [CrossRef]

7. Gopal, R.; Lin, Y.; Obermajer, N.; Slight, S.; Nuthalapati, N.; Ahmed, M.; Khader, S.A. IL-23-dependent IL-17 drives Th1-cell responses following Mycobacterium bovis BCG vaccination. Eur. J. Immunol. 2012, 42, 364-373. [CrossRef] [PubMed]

8. Chatterjee, S.; Dwivedi, V.P.; Singh, Y.; Siddiqui, I.; Sharma, P.; Van Kaer, L.; Chattopadhyay, D.; Das, G. Early Secreted Antigen ESAT-6 of Mycobacterium tuberculosis Promotes Protective T Helper 17 Cell Responses in a Toll-Like Receptor-2-dependent Manner. PLoS Pathog. 2011, 7, e1002378. [CrossRef] [PubMed]

9. Torrado, E.; Cooper, A.M. IL-17 and Th17 cells in tuberculosis. Cytokine Growth Factor Rev. 2010, 21, 455-462. [CrossRef] [PubMed]

10. Flower, R.J. The development of COX2 inhibitors. Nat. Rev. Drug Discov. 2003, 2, 179-191. [CrossRef]

11. Harris, S.G.; Padilla, J.; Koumas, L.; Ray, D.; Phipps, R.P. Prostaglandins as modulators of immunity. Trends Immunol. 2002, 23, 144-150. [CrossRef]

12. Sheibanie, A.F.; Khayrullina, T.; Safadi, F.F.; Ganea, D. Prostaglandin E2 exacerbates collagen-induced arthritis in mice through the inflammatory interleukin-23/interleukin-17 axis. Arthritis Rheum. 2007, 56, 2608-2619. [CrossRef] [PubMed]

13. Sheibanie, A.F.; Yen, J.-H.; Khayrullina, T.; Emig, F.; Zhang, M.; Tuma, R.F.; Ganea, D. The Proinflammatory Effect of Prostaglandin E2 in Experimental Inflammatory Bowel Disease Is Mediated through the IL-23 $\rightarrow$ IL-17 Axis. J. Immunol. 2007, 178, 8138-8147. [CrossRef]

14. Sheibanie, A.F.; Tadmori, I.; Jing, H.; Vassiliou, E.; Ganea, D. Prostaglandin E2 induces IL-23 production in bone marrow-derived dendritic cells. FASEB J. 2004, 18, 1318-1320. [CrossRef]

15. Chizzolini, C.; Chicheportiche, R.; Alvarez, M.; de Rham, C.; Roux-Lombard, P.; Ferrari-Lacraz, S.; Dayer, J.M. Prostaglandin E2 synergistically with interleukin-23 favors human Th17 expansion. Blood 2008, 112, 3696-3703. [CrossRef] [PubMed]

16. Weaver, C.T.; Hatton, R.; Mangan, P.R.; Harrington, L.E. IL-17 Family Cytokines and the Expanding Diversity of Effector T Cell Lineages. Annu. Rev. Immunol. 2007, 25, 821-852. [CrossRef]

17. Bettelli, E.; Oukka, M.; Kuchroo, V.K. T(H)-17 cells in the circle of immunity and autoimmunity. Nat. Immunol. 2007, 8, 345-350. [CrossRef] [PubMed]

18. Dong, C. Diversification of T-helper-cell lineages: Finding the family root of IL-17-producing cells. Nat. Rev. Immunol. 2006, 6, 329-333. [CrossRef]

19. McKenzie, B.S.; Kastelein, R.A.; Cua, D.J. Understanding the IL-23-IL-17 immune pathway. Trends Immunol. 2006, $27,17-23$. [CrossRef]

20. Kebir, H.; Kreymborg, K.; Ifergan, I.; Dodelet-Devillers, A.; Cayrol, R.; Bernard, M.; Giuliani, F.; Arbour, N.; Becher, B.; Prat, A.; et al. Human TH17 lymphocytes promote blood-brain barrier disruption and central nervous system inflammation. Nat. Med. 2007, 13, 1173-1175. [CrossRef] [PubMed] 
21. Annunziato, F.; Cosmi, L.; Santarlasci, V.; Maggi, L.; Liotta, F.; Mazzinghi, B.; Parente, E.; Filì, L.; Ferri, S.; Frosali, F.; et al. Phenotypic and functional features of human Th17 cells. J. Exp. Med. 2007, 204, 1849-1861. [CrossRef]

22. Wilson, N.J.; Boniface, K.; Chan, J.R.; McKenzie, B.S.; Blumenschein, W.M.; Mattson, J.D.; de Waal Malefyt, R.; Basham, B.; Smith, K.; Chen, T.; et al. Development, cytokine profile and function of human interleukin 17-producing helper T cells. Nat. Immunol. 2007, 8, 950-957. [CrossRef] [PubMed]

23. Hirota, K.; Yoshitomi, H.; Hashimoto, M.; Maeda, S.; Teradaira, S.; Sugimoto, N.; Yamaguchi, T.; Nomura, T.; Ito, H.; Nakamura, T.; et al. Preferential recruitment of CCR6-expressing Th17 cells to inflamed joints via CCL20 in rheumatoid arthritis and its animal model. J. Exp. Med. 2007, 204, 2803-2812. [CrossRef] [PubMed]

24. Acosta-Rodriguez, E.V.; Napolitani, G.; Lanzavecchia, A.; Sallusto, F. Interleukins 1beta and 6 but not transforming growth factor-beta are essential for the differentiation of interleukin 17-producing human T helper cells. Nat. Immunol. 2007, 8, 942-949. [CrossRef] [PubMed]

25. Chen, Z.; Tato, C.M.; Muul, L.M.; Laurence, A.; O'Shea, J.J. Distinct regulation of interleukin-17 in human T helper lymphocytes. Arthritis Rheum. 2007, 56, 2936-2946. [CrossRef]

26. McGeachy, M.J.; Cua, D.J. The link between IL-23 and Th17 cell-mediated immune pathologies. Semin. Immunol. 2007, 19, 372-376. [CrossRef]

27. Nore, K.G.; Jorgensen, M.J.; Dyrhol-Riise, A.M.; Jenum, S.; Tonby, K. Elevated Levels of Anti-Inflammatory Eicosanoids and Monocyte Heterogeneity in Mycobacterium tuberculosis Infection and Disease. Front. Immunol. 2020, 11, 579849. [CrossRef]

28. Kaul, V.; Bhattacharya, D.; Singh, Y.; Van Kaer, L.; Peters-Golden, M.; Bishai, W.R.; Das, G. An Important Role of Prostanoid Receptor EP2 in Host Resistance to Mycobacterium tuberculosis Infection in Mice. J. Infect. Dis. 2012, 206, 1816-1825. [CrossRef]

29. Mayer-Barber, K.D.; Andrade, B.B.; Oland, S.D.; Amaral, E.; Barber, D.L.; Gonzales, J.; Derrick, S.C.; Shi, R.; Kumar, N.P.; Wei, W.; et al. Host-directed therapy of tuberculosis based on interleukin-1 and type I interferon crosstalk. Nature 2014, 511, 99-103. [CrossRef]

30. Tufariello, J.M.; Jacobs, J.W.R.; Chan, J. Individual Mycobacterium tuberculosis Resuscitation-Promoting Factor Homologues Are Dispensable for Growth In Vitro and In Vivo. Infect. Immun. 2004, 72, 515-526. [CrossRef]

31. Fenhalls, G.; Stevens, L.; Moses, L.; Bezuidenhout, J.; Betts, J.; van Helden, P.; Lukey, P.T.; Duncan, K. In Situ Detection of Mycobacterium tuberculosis Transcripts in Human Lung Granulomas Reveals Differential Gene Expression in Necrotic Lesions. Infect. Immun. 2002, 70, 6330-6338. [CrossRef] [PubMed]

32. Downing, K.; Betts, J.; Young, D.; McAdam, R.; Kelly, F.; Young, M.; Mizrahi, V. Global expression profiling of strains harbouring null mutations reveals that the five rpf-like genes of Mycobacterium tuberculosis show functional redundancy. Tuberculosis 2004, 84, 167-179. [CrossRef]

33. Gupta, R.K.; Srivastava, B.S.; Srivastava, R. Comparative expression analysis of rpf-like genes of Mycobacterium tuberculosis H37Rv under different physiological stress and growth conditions. Microbiology 2010, 156, 2714-2722. [CrossRef]

34. Romano, M.; Aryan, E.; Korf, H.; Bruffaerts, N.; Franken, C.L.; Ottenhoff, T.H.; Huygen, K. Potential of Mycobacterium tuberculosis resuscitation-promoting factors as antigens in novel tuberculosis sub-unit vaccines. Microbes Infect. 2012, 14, 86-95. [CrossRef]

35. Boniface, K.; Bak-Jensen, K.S.; Li, Y.; Blumenschein, W.M.; McGeachy, M.J.; McClanahan, T.K.; McKenzie, B.S.; Kastelein, R.A.; Cua, D.J.; Malefyt, R.D.W. Prostaglandin E2 regulates Th17 cell differentiation and function through cyclic AMP and EP2/EP4 receptor signaling. J. Cell Biol. 2009, 184, i16. [CrossRef]

36. Yao, C.; Sakata, D.; Esaki, Y.; Li, Y.; Matsuoka, T.; Kuroiwa, K.; Sugimoto, Y.; Narumiya, S. Prostaglandin E2-EP4 signaling promotes immune inflammation through TH1 cell differentiation and TH17 cell expansion. Nat. Med. 2009, 15, 633-640. [CrossRef] [PubMed]

37. Bloom, D.; Jabrane-Ferrat, N.; Zeng, L.; Wu, A.; Li, L.; Lo, D.; Goetzl, E.J. Prostaglandin E2 enhancement of interferon-gamma production by antigen-stimulated type 1 helper T cells. Cell. Immunol. 1999, 194, 21-27. [CrossRef] [PubMed]

38. Flaherty, S.; Reynolds, J.M. Mouse Naïve CD4 ${ }^{+}$T Cell Isolation and In vitro Differentiation into T Cell Subsets. J. Vis. Exp. 2015, 98, e52739. [CrossRef]

39. Sreeramkumar, V.; Fresno, M.; Cuesta, N. Prostaglandin E2 and T cells: Friends or foes? Immunol. Cell Biol. 2012, 90, 579-586. [CrossRef]

40. Kalinski, P. Regulation of Immune Responses by Prostaglandin E2. J. Immunol. 2011, 188, 21-28. [CrossRef] [PubMed]

41. Lindenstrøm, T.; Agger, E.M.; Korsholm, K.S.; Darrah, P.A.; Aagaard, C.; Seder, R.A.; Rosenkrands, I.; Andersen, P. Tuberculosis Subunit Vaccination Provides Long-Term Protective Immunity Characterized by Multifunctional CD4 Memory T Cells. J. Immunol. 2009, 182, 8047-8055. [CrossRef] [PubMed]

42. Derrick, S.C.; Yabe, I.M.; Yang, A.; Morris, S.L. Vaccine-induced anti-tuberculosis protective immunity in mice correlates with the magnitude and quality of multifunctional CD4 T cells. Vaccine 2011, 29, 2902-2909. [CrossRef] [PubMed]

43. Allie, N.; Grivennikov, S.I.; Keeton, R.; Hsu, N.-J.; Bourigault, M.-L.; Court, N.; Fremond, C.; Yeremeev, V.; Shebzukhov, Y.; Ryffel, B.; et al. Prominent role for T cell-derived Tumour Necrosis Factor for sustained control of Mycobacterium tuberculosis infection. Sci. Rep. 2013, 3, srep01809. [CrossRef]

44. Segueni, N.; Benmerzoug, S.; Rose, S.; Gauthier, A.; Bourigault, M.L.; Reverchon, F.; Philippeau, A.; Erard, F.; Le Bert, M.; Bouscayrol, H.; et al. Innate myeloid cell TNFR1 mediates first line defence against primary Mycobacterium tuberculosis infection. Sci. Rep. 2016, 6, 22454. [CrossRef] [PubMed] 
45. Filipe-Santos, O.; Bustamante, J.; Chapgier, A.; Vogt, G.; de Beaucoudrey, L.; Feinberg, J.; Jouanguy, E.; Boisson-Dupuis, S.; Fieschi, C.; Picard, C.; et al. Inborn errors of IL-12/23- and IFN-gamma-mediated immunity: Molecular, cellular, and clinical features. Semin. Immunol. 2006, 18, 347-361. [CrossRef] [PubMed]

46. Choi, H.G.; Kwon, K.W.; Choi, S.; Back, Y.W.; Park, H.S.; Kang, S.M. Antigen-Specific IFN-gamma/IL-17-Co-Producing CD4(+) T-Cells Are the Determinants for Protective Efficacy of Tuberculosis Subunit Vaccine. Vaccines 2020, 8, 300. [CrossRef]

47. Goldsack, L.; Kirman, J.R. Half-truths and selective memory: Interferon gamma, $\mathrm{CD} 4^{+} \mathrm{T}$ cells and protective memory against tuberculosis. Tuberculosis 2007, 87, 465-473. [CrossRef]

48. Tchilian, E.Z.; Desel, C.; Forbes, E.K.; Bandermann, S.; Sander, C.R.; Hill, A.V. Immunogenicity and protective efficacy of prime-boost regimens with recombinant (delta)ureC hly+ Mycobacterium bovis BCG and modified vaccinia virus ankara expressing M. tuberculosis antigen 85A against murine tuberculosis. Infect. Immun. 2009, 77, 622-631. [CrossRef]

49. Leal, I.S.; Smedegård, B.; Andersen, P.; Appelberg, R. Failure to induce enhanced protection against tuberculosis by increasing T-cell-dependent interferon-gamma generation. Immunology 2001, 104, 157-161. [CrossRef]

50. Vilaplana, C.; Prats, C.; Marzo, E.; Barril, C.; Vegue, M.; Diaz, J.; Valls, J.; Cardona, P. To achieve an earlier IFN-gamma response is not sufficient to control Mycobacterium tuberculosis infection in mice. PLoS ONE 2014, 9, e100830. [CrossRef]

51. Gallegos, A.M.; Van Heijst, J.W.J.; Samstein, M.; Su, X.; Pamer, E.G.; Glickman, M.S. A Gamma Interferon Independent Mechanism of CD4 T Cell Mediated Control of M. tuberculosis Infection in vivo. PLoS Pathog. 2011, 7, e1002052. [CrossRef]

52. Torrado, E.; Cooper, A.M. What do we really know about how CD4 T cells control Mycobacterium tuberculosis? PLoS Pathog. 2011, 7, e1002196. [CrossRef]

53. Orr, M.T.; Ireton, G.C.; Beebe, E.A.; Huang, P.-W.D.; Reese, V.A.; Argilla, D.; Coler, R.N.; Reed, S.G. Immune Subdominant Antigens as Vaccine Candidates against Mycobacterium tuberculosis. J. Immunol. 2014, 193, 2911-2918. [CrossRef]

54. Gopal, R.; Monin, L.; Slight, S.; Uche, U.; Blanchard, E.; Junecko, B.A.F.; Ramos-Payan, R.; Stallings, C.L.; Reinhart, T.A.; Kolls, J.K.; et al. Unexpected Role for IL-17 in Protective Immunity against Hypervirulent Mycobacterium tuberculosis HN878 Infection. PLoS Pathog. 2014, 10, e1004099. [CrossRef]

55. Cruz, A.; Torrado, E.; Carmona, J.; Fraga, A.G.; Costa, P.; Rodrigues, F.; Appelberg, R.; Correia-Neves, M.; Cooper, A.M.; Saraiva, M.; et al. BCG vaccination-induced long-lasting control of Mycobacterium tuberculosis correlates with the accumulation of a novel population of CD4(+)IL-17(+)TNF(+)IL-2(+) T cells. Vaccine 2015, 33, 85-91. [CrossRef] [PubMed]

56. Aguilo, N.; Arguedas, S.Á.; Uranga, S.; Marinova, D.; Monzón, M.; Badiola, J.; Martin, C. Pulmonary but Not Subcutaneous Delivery of BCG Vaccine Confers Protection to Tuberculosis-Susceptible Mice by an Interleukin 17-Dependent Mechanism. J. Infect. Dis. 2016, 213, 831-839. [CrossRef]

57. Wareham, A.S.; Tree, J.A.; Marsh, P.D.; Butcher, P.D.; Dennis, M.; Sharpe, S.A. Evidence for a Role for Interleukin-17, Th17 Cells and Iron Homeostasis in Protective Immunity against Tuberculosis in Cynomolgus Macaques. PLoS ONE 2014, 9, e88149. [CrossRef]

58. Dijkman, K.; Sombroek, C.C.; Vervenne, R.A.W.; Hofman, S.O.; Boot, C.; Remarque, E.J.; Kocken, C.; Ottenhoff, T.H.M.; Kondova, I.; Khayum, M.A.; et al. Prevention of tuberculosis infection and disease by local BCG in repeatedly exposed rhesus macaques. Nat. Med. 2019, 25, 255-262. [CrossRef]

59. Shen, H.; Chen, Z.W. The crucial roles of Th17-related cytokines/signal pathways in M. tuberculosis infection. Cell. Mol. Immunol. 2018, 15, 216-225. [CrossRef] [PubMed]

60. Mourik, B.C.; Lubberts, E.; De Steenwinkel, J.E.M.; Ottenhoff, T.H.M.; Leenen, P.J.M. Interactions between Type 1 Interferons and the Th17 Response in Tuberculosis: Lessons Learned from Autoimmune Diseases. Front. Immunol. 2017, 8, 294. [CrossRef] [PubMed]

61. Scriba, T.J.; Penn-Nicholson, A.; Shankar, S.; Hraha, T.; Thompson, E.G.; Sterling, D.; Nemes, E.; Darboe, F.; Suliman, S.; Amon, L.M.; et al. Sequential inflammatory processes define human progression from $M$. tuberculosis infection to tuberculosis disease. PLoS Pathog. 2017, 13, e1006687. [CrossRef]

62. Goodwin, J.S.; Ceuppens, J. Regulation of the immune response by prostaglandins. J. Clin. Immunol. 1983, 3, 295-315. [CrossRef]

63. Hasler, F.; Bluestein, H.G.; Zvaifler, N.J.; Epstein, L.B. Analysis of the defects responsible for the impaired regulation of EBVinduced B cell proliferation by rheumatoid arthritis lymphocytes. II. Role of monocytes and the increased sensitivity of rheumatoid arthritis lymphocytes to prostaglandin E. J. Immunol. 1983, 131, 768-772.

64. Chen, M.; Divangahi, M.; Gan, H.; Shin, D.S.; Hong, S.; Lee, D.M.; Serhan, C.N.; Behar, S.; Remold, H.G. Lipid mediators in innate immunity against tuberculosis: Opposing roles of PGE2 and LXA4 in the induction of macrophage death. J. Exp. Med. 2008, 205, 2791-2801. [CrossRef] [PubMed]

65. Akira, S.; Takeda, K.; Kaisho, T. Toll-like receptors: Critical proteins linking innate and acquired immunity. Nat. Immunol. 2001, 2, 675-680. [CrossRef]

66. Nishigaki, N.; Negishi, M.; Ichikawa, A. Two Gs-coupled Prostaglandin E receptor subtypes, EP2 and EP4, differ in desensitization and sensitivity to the metabolic inactivation of the agonist. Folia Pharmacol. Jpn. 1996, 108, 65-69. [CrossRef]

67. Sakata, D.; Yao, C.; Narumiya, S. Prostaglandin E2, an immunoactivator. J. Pharmacol. Sci. 2010, 112, 1-5. [CrossRef] [PubMed]

68. Lach, H.; Surowiak, J.; Dziubek, K.; Krawczyk, S.; Szaroma, W.; Koczanowski, B. Influence of ethanol on glutathione level in the blood, liver and kidneys of Rana temporaria L. in the annual cycle. Acta Biol. Hung. 1987, 38, 185-194.

69. Hwang, E.S.; Szabo, S.J.; Schwartzberg, P.L.; Glimcher, L.H. T helper cell fate specified by kinase-mediated interaction of T-bet with GATA-3. Science 2005, 307, 430-433. [CrossRef] 
70. Veldhoen, M.; Hocking, R.J.; Atkins, C.J.; Locksley, R.M.; Stockinger, B. TGFbeta in the context of an inflammatory cytokine milieu supports de novo differentiation of IL-17-producing T cells. Immunity 2006, 24, 179-189. [CrossRef] [PubMed]

71. Mangan, P.R.; Harrington, L.E.; O'Quinn, D.B.; Helms, W.S.; Bullard, D.C.; Elson, C.O.; Weaver, C.T. Transforming growth factor-beta induces development of the $\mathrm{T}(\mathrm{H}) 17$ lineage. Nature 2006, 441, 231-234. [CrossRef] [PubMed]

72. Ivanov, I.I.; McKenzie, B.S.; Zhou, L.; Tadokoro, C.E.; Lepelley, A.; Lafaille, J.J.; Cua, D.J.; Littman, D.R. The orphan nuclear receptor RORgammat directs the differentiation program of proinflammatory IL-17+ T helper cells. Cell 2006, 126, 1121-1133. [CrossRef]

73. Bettelli, E.; Carrier, Y.; Gao, W.; Korn, T.; Strom, T.B.; Oukka, M.; Weiner, H.L.; Kuchroo, V.K. Reciprocal developmental pathways for the generation of pathogenic effector TH17 and regulatory T cells. Nature 2006, 441, 235-238. [CrossRef]

74. Kurumaya, H.; Yoshida, K.; Kono, N.; Nakanuma, Y.; Takeda, S.; Oiko, Y. Hepatic calcification in proliferated bile ductules in a uremic patient. Arch. Pathol. Lab. Med. 1989, 113, 411-413.

75. Cua, D.J.; Sherlock, J.; Chen, Y.; Murphy, C.A.; Joyce, B.; Seymour, B.; Lucian, L.; To, W.; Kwan, S.; Churakova, T.; et al. Interleukin23 rather than interleukin-12 is the critical cytokine for autoimmune inflammation of the brain. Nature 2003, 421,744-748. [CrossRef] [PubMed]

76. Modlin, H.C. Compensation neurosis. Bull. Am. Acad. Psychiatry Law 1986, 14, 263-271. [PubMed]

77. Santarlasci, V.; Maggi, L.; Capone, M.; Frosali, F.; Querci, V.; De Palma, R. TGF-beta indirectly favors the development of human Th17 cells by inhibiting Th1 cells. Eur. J. Immunol. 2009, 39, 207-215. [CrossRef] [PubMed]

78. Hebel, K.; Rudolph, M.; Kosak, B.; Chang, H.D.; Butzmann, J.; Brunner-Weinzierl, M.C. IL-1beta and TGF-beta act antagonistically in induction and differentially in propagation of human proinflammatory precursor CD4+ T cells. J. Immunol. 2011, 187, 5627-5635. [CrossRef] [PubMed]

79. Napolitani, G.; Acosta-Rodriguez, E.V.; Lanzavecchia, A.; Sallusto, F. Prostaglandin E2 enhances Th17 responses via modulation of IL-17 and IFN-gamma production by memory CD4+ T cells. Eur. J. Immunol. 2009, 39, 1301-1312. [CrossRef]

80. Lyadova, I.V.; Panteleev, A.V. Th1 and Th17 Cells in Tuberculosis: Protection, Pathology, and Biomarkers. Mediat. Inflamm. 2015, 2015, 854507. [CrossRef]

81. Nikitina, I.Y.; Panteleev, A.V.; Kosmiadi, G.A.; Serdyuk, Y.V.; Nenasheva, T.A.; Nikolaev, A.A. Th1, Th17, and Th1Th17 Lymphocytes during Tuberculosis: Th1 Lymphocytes Predominate and Appear as Low-Differentiated CXCR3(+)CCR6(+) Cells in the Blood and Highly Differentiated CXCR3(+/-)CCR6(-) Cells in the Lungs. J. Immunol. 2018, 200, 2090-2103. [CrossRef] [PubMed]

82. Choi, H.-G.; Choi, S.; Back, Y.W.; Paik, S.; Park, H.-S.; Kim, W.S.; Kim, H.; Bin Cha, S.; Choi, C.H.; Shin, S.J.; et al. Rv2299c, a novel dendritic cell-activating antigen of Mycobacterium tuberculosis, fused-ESAT-6 subunit vaccine confers improved and durable protection against the hypervirulent strain HN878 in mice. Oncotarget 2017, 8, 19947-19967. [CrossRef] [PubMed]

83. Byun, E.-H.; Kim, W.S.; Shin, A.-R.; Kim, J.-S.; Whang, J.; Won, C.-J.; Choi, Y.; Kim, S.-Y.; Koh, W.J.; Kim, H.-J.; et al. Rv0315, a novel immunostimulatory antigen of Mycobacterium tuberculosis, activates dendritic cells and drives Th1 immune responses. J. Mol. Med. 2012, 90, 285-298. [CrossRef] [PubMed] 